\title{
العنف الأسرى ضد الأطفال
}

أ. إيمان عبدالله السيد
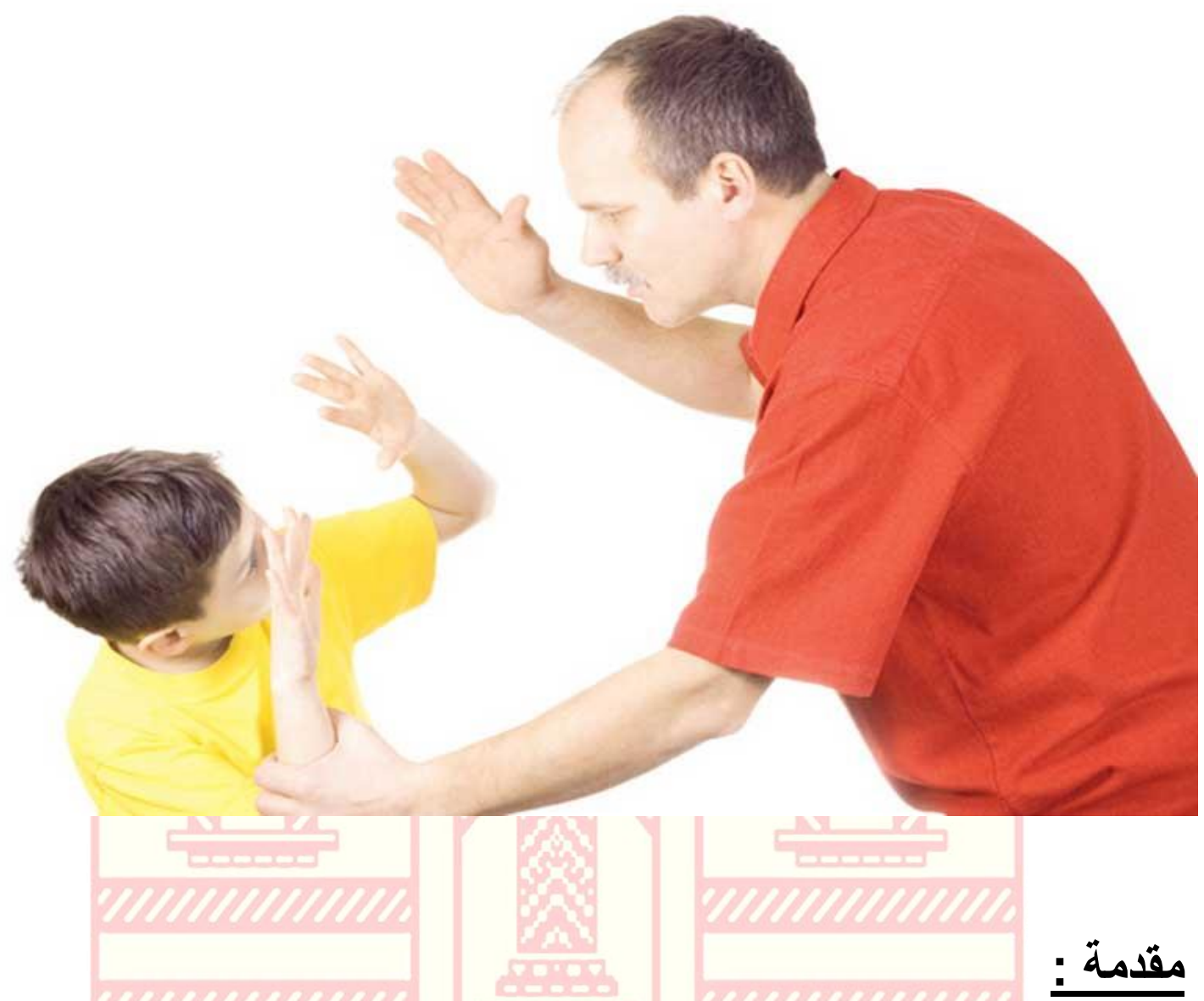

العنف الأسرى قديم قدم الإنسان، فأول جريمة عرفتها البشرية بين ابنى آدم هابيل وقابيل

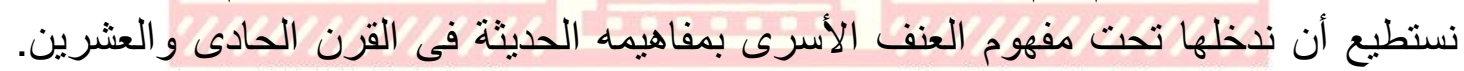
ويرتبط هذا النوع من السلوك الإنسانى بالأسرة ويستمد حساسيته البالغة من أهمية الأسرة في لهئ

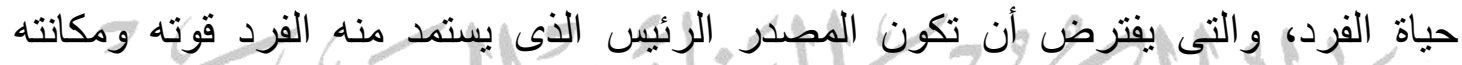
الاجتماعية وإحساسه بالامن والراحة النفسية، إلا أن هذه الوظيفة تختل في بعض الأن الاحيان،

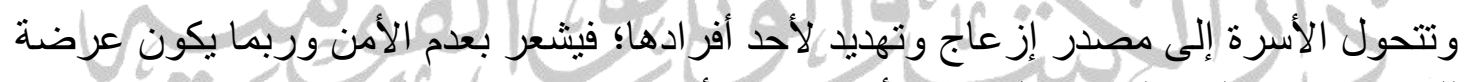
للعنف وإسباءة المعاملة من قبل بعض الفر ألفر اد هذه الأسرة.

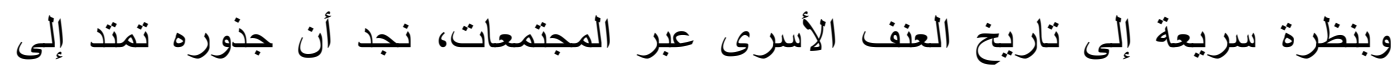

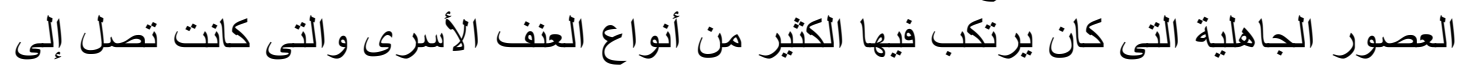

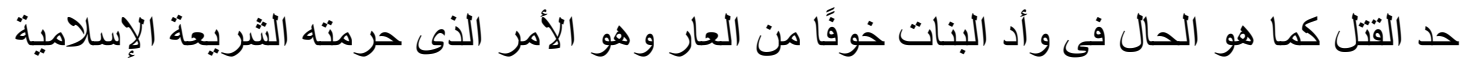

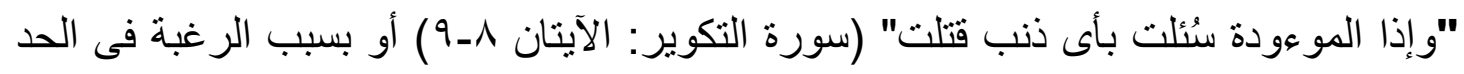

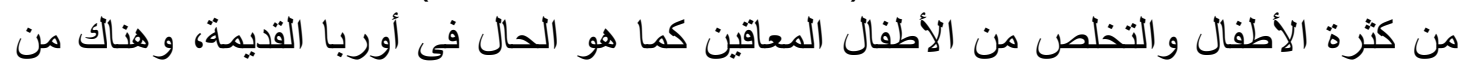

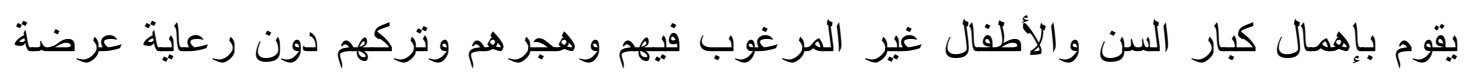

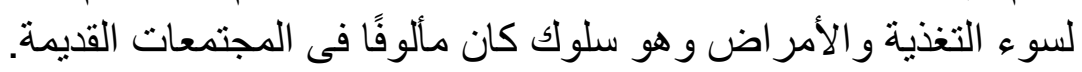


ورغم قدم هذه الظاهرة إلا أن الاهتمام بها-كظاهرة اجتماعية، تستحق الدراسة وتستدعى

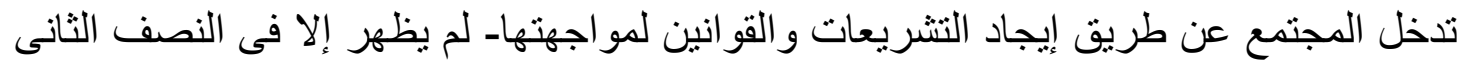

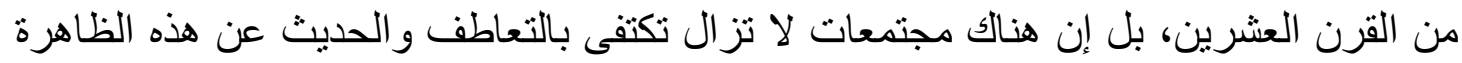

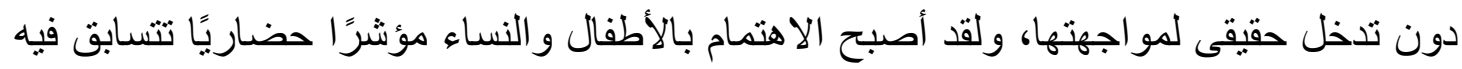

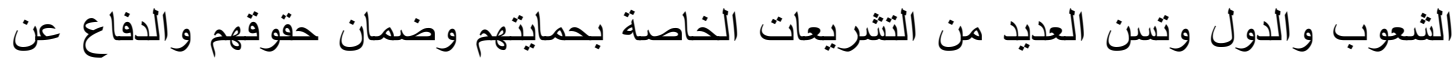

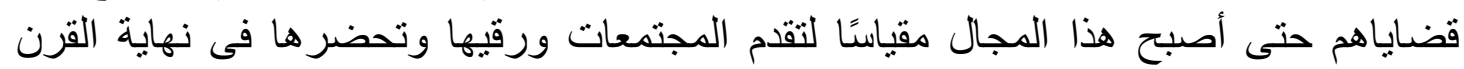

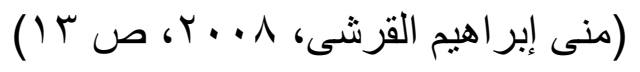
العشرين.

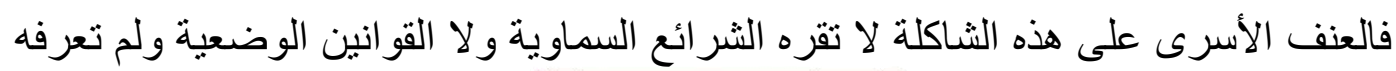

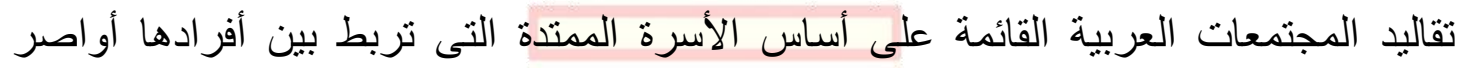

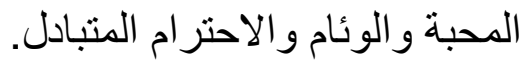

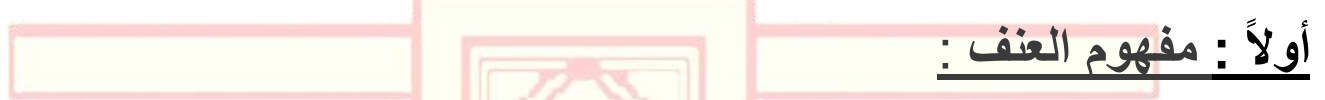
هناك عدة مفاهيم اللعنف منها

ـ- استخدام القوة المادية أو المعنوية لإلحاق الأذى بآخر استخدامًا مشروعًا أو غير مشروع. - مشن

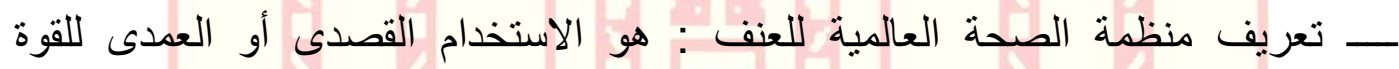
أو السلطة، أو التهديد بذلك، ضد الذات أو ضد شخص : هو آخر أو عدد من الأشخاص

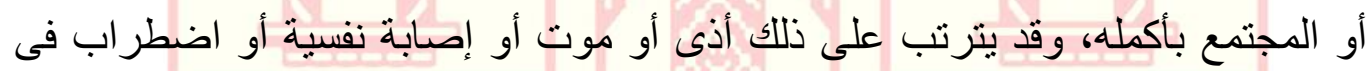

$$
\text { النمو أو حرمان }
$$

ويتسع هذا التعريف للعنف ليشمل جميع أشكال العنف الجسدى و النفسى، كما يتضمن الإهمال المتعدد أو المعاملة السيئة أو الاستغلال الجنسى للأطفال، ويأخذ الأمر منحى أكثر خطورة حين يكون مصدر العنف من القائمين على رعاية الطفل أو المسئولين عنه. ومما سبق من التعريفات السابقة بتضح أن للعنف علاقة قوية بالسلوك وهو نقل السلوك من

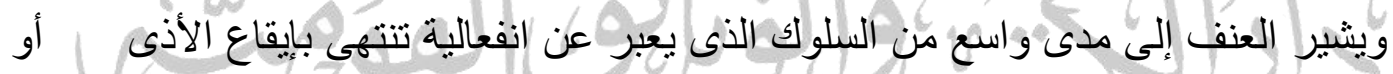

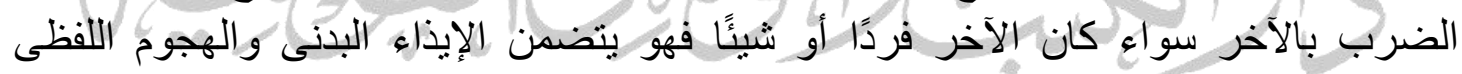
وتحطيم الممتلكات وقد يصل إلى حد التهديد بالقتل أو القتل فعلاً.

وهنالك عدة مفاهيم ارتبطت بالعنف منها :

$$
\text { - ــ - الغضب. - العدوان. }
$$




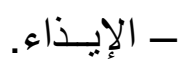

و لا يمكن در اسة العنف دون النظر و الإشارة إلى هذه المتغير ات فمثلاً : ـ العنف والغضب : إن الغضب الزائد له كثير من الآثار السلبية على الثخص والأسرة

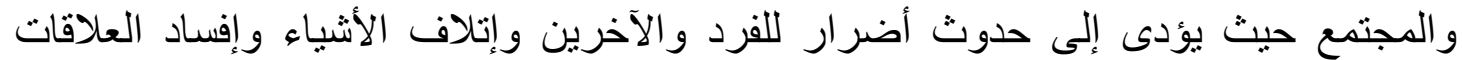
الاجتماعية بين الفرد وغيره كما يعد العنف مظهر من مظاهر الغضب. ب - العنف والعدوان : يرتبط العنف بالعدوان بتعمد الأذى والتخريب، و التخريب فى حد ذاته يعتبر عنفًا و عدوانًا.

ويعرف العدوان بأنه سلوك القصد منه إحداث الضرر الجسمى والنفسى بشخص ما ماد أو إحداث تلف مادى لثىء ما، كما أن العنف هو الجانب النشط من العدوان.

ج - العنف والقوة : القوة هى القرة على فرض إر ادة شخص ما و التحكم فى الآخرين بطريقة شرعية أو غير شرعية، وهى القدرة على التحكم فى سلوك الآخرين برغبتهم أو بدون رغوة رغبتهم حتى و إن كانت هنالك مقاومة من أنسر الآخرين.

د - العنف والإيذاء: والإيذاء هو الاعتداء الجسدى على الأفراد رغمًا عنهم و الإيذاء لله أشكال عديدة مثل الضرب أو القتل أو القهر الجنسى أو الاعتداء الجسدى أيضًا ويختلف الإيذاء باختلاف درجته و تأثنيره على الآخرين.

ومما سبق يتضح لنا أن المقصود بجر ائم العنف هى كل الجرائم التى تستخدم فيها القوة

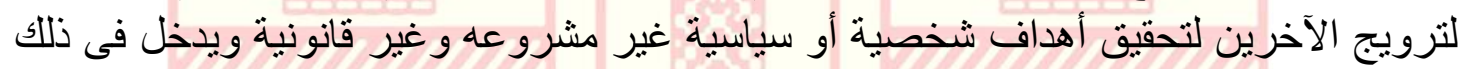
أيضًا جر ائم الحر ابة كالسرقة بالإكر اه أو السطو المسلح و الاغنصاب و والبلطجة و الإر هاب كما

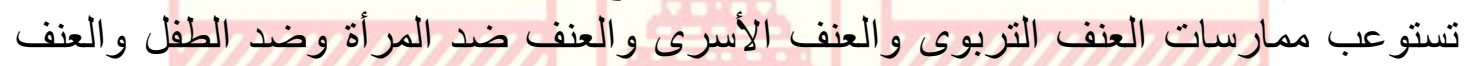
النفسى بجميع أشكاله.

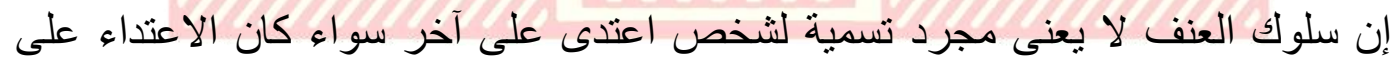
أبيه أو أمه أو زوجته أو جده أو أخيه بل الأمر يتوقف على لئى الخبراء من الناحية الاجتماعية

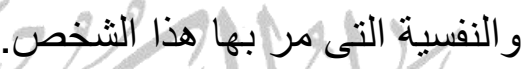
وخلاصلة القول أن العنف يعتبر ناتجًا لظروف اجتماعية تتمنل فى الأوضاع العالمية

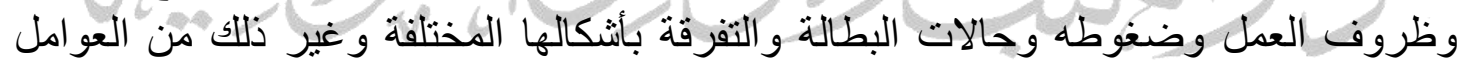
الاجتماعية و الاقتصادية.

abdu09945.blogspot.com/2013/05/blog-post_7145.htm

ثانيًا : تعريف مفهوم العنف الأسرى :

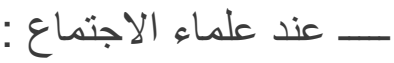

هو أحد أنماط السلوك العدوانى الذى ينتج عن وجود علاقات غير متكافئة فى إطار نظام 
تقسيم العمل بين المرأة والرجل داخل الأسرة، وما يترتب على ذللك من تحديد لأدوار ومكانة

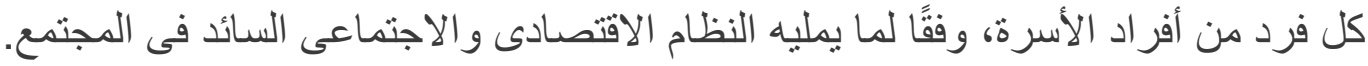

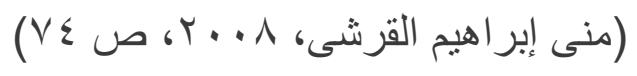

ويشمل عنف الزوج تجاه زوجته، و عنف الزوجة تجاه زوجها، و عنف الو الدين تجاه الأولاد

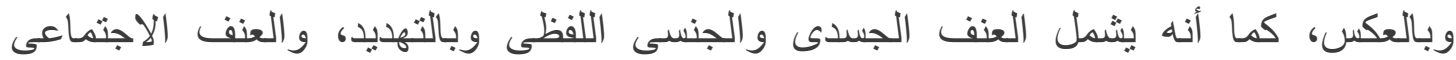

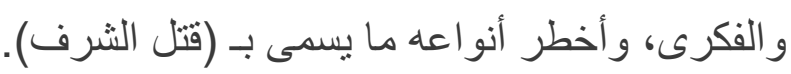

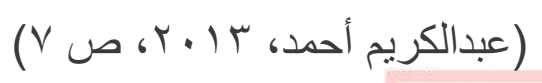

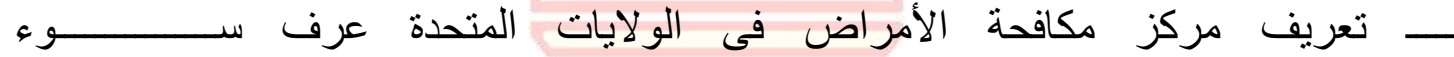

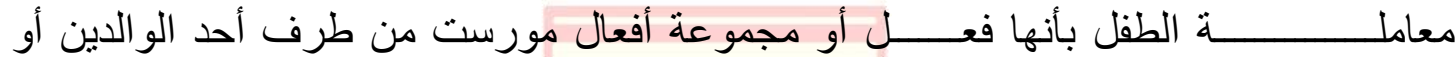

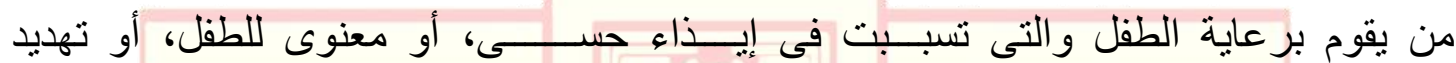

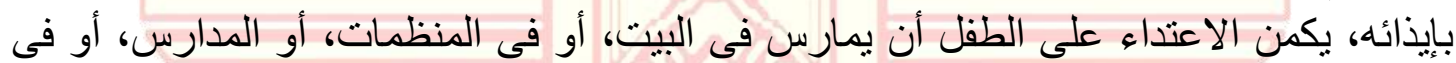

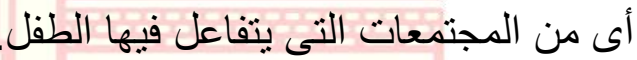

\section{(mawdoo3.com )}

وفى نظرة تفصيلية لبيان حكم الإسلام فى العنف الموجه ضد الأطفال وفق النظرة الدولية

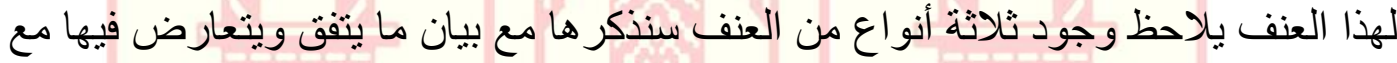
الثريعة الإسلامية.

أ-الاعتداء أو الأذى العاطفى : هو إلحاق الضرر النفسى والاجتماعى بالطفل، وذللك من خلال

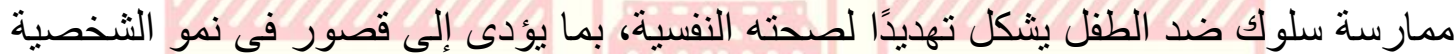
لديه، و اضطر اب في العلاقة الاجتماعية بالآخرين . بـالحرمان والإهمال والتليل الزائد : كحرمان الطفل من اللعب و الحنان و الرعاية، ومن حقه فى التعليم واللعب، والقسوة فى المعاملة أو التدليل الزائد و الحماية المسرفة النئ.

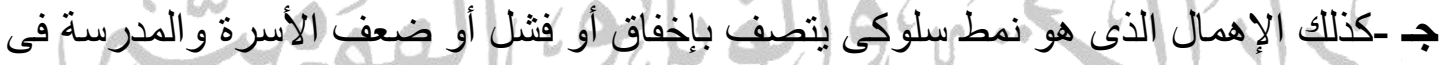

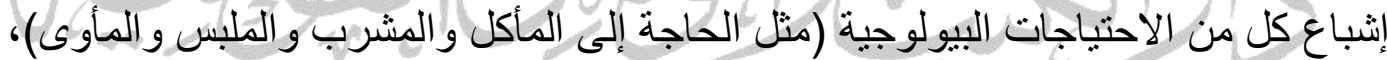
و الاحتباجات النفسية (مثل الحاجة إلى الأمن و الأمان، والرانية الرعاية).

و هذا النوع من العنف نبذه الإسلام، حيث كان من هدى النبى صلى الله عليه وسلم

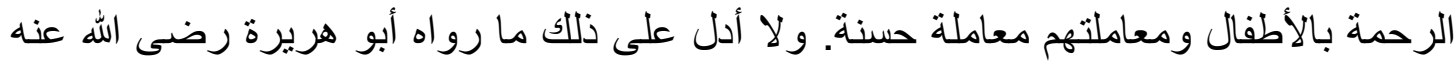

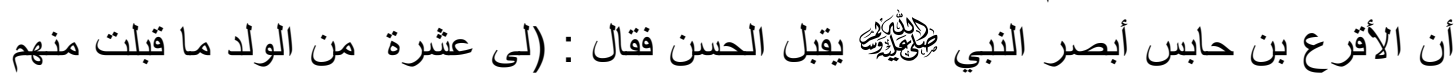

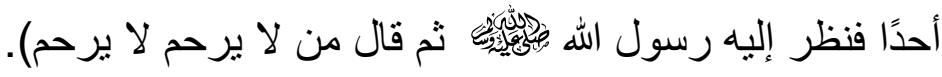

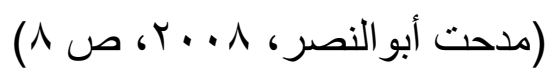


بـالزواج المبكر : عُرِّف الطفل فى الاتفاقية الدولية لحقوق الطفل، بأنه : "هو كل إنسان لم

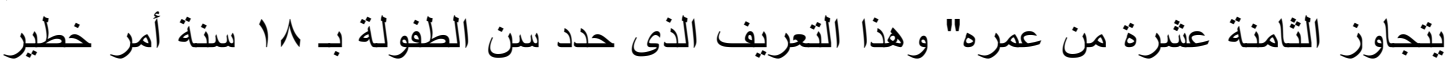

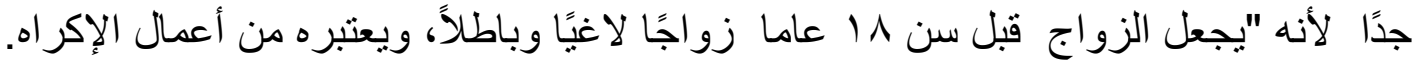

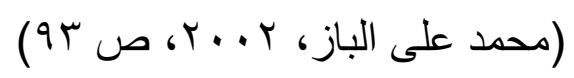

أشكال العنف الأسرى : (1) ل اللعنف الأسرى عدة مسميات و أنثكال : ا ـ العنف اللفظى : و المتمثل فى السب و التوبيخ.

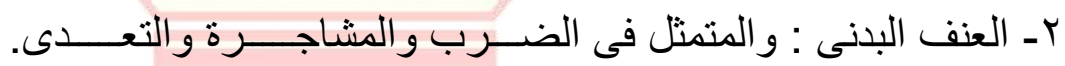
rـ العنف التنفيذى : و المتمثل فى القتل و التعدى على الآخرين وممتلكاتهم بالقوة

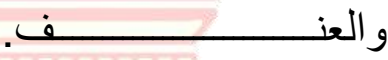
أنواع العنف الأسرى :

أـ العنف اللا عقلانى : أى غير المسئول الذى يفتقد إلى أية أهداف موضوعية يثور ضدها.

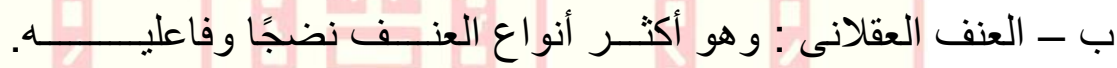
ج - العنف الانفعالى : وهو نوع من الانفجار العاطفى الذى يعبر عن توترات ومشاعر متر اكمة لها أسبابها.

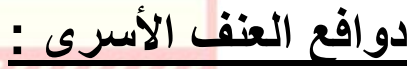

إن الدو افع التى يندفع الإنسان بمقتضاها نحو العنف الأسرى يمكن تقسيمها إلى قسمين هما :

\section{1- الدوافع الذاتية البيئية :}

ونعنى بهذا النوع من الدو افع التي تتبع من ذات الإنسان، ونفسته، و التىى تقوده نحو العنف

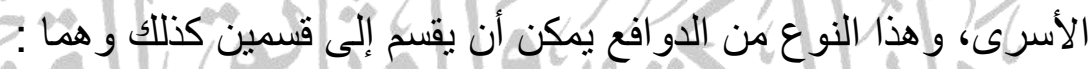

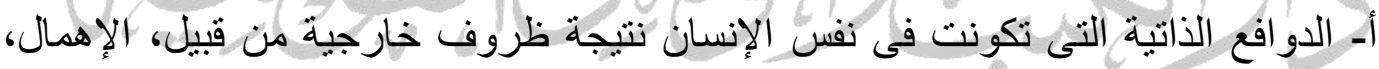

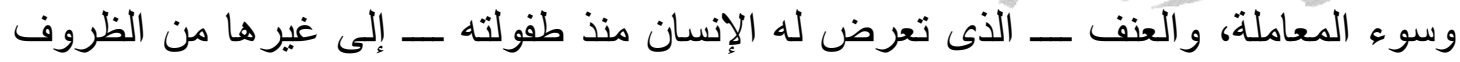

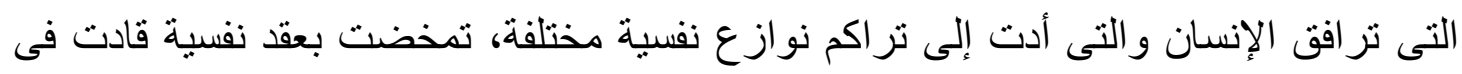

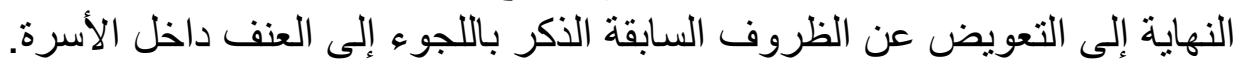
لقد أثتتت الدراسات الحديثة بأن الطفل الذى يتعرض للعنف إبان فترة طفولته يكون أكثر

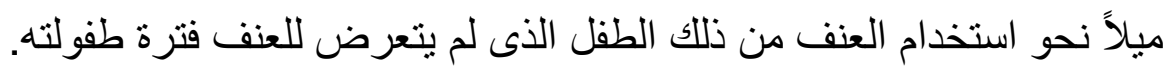

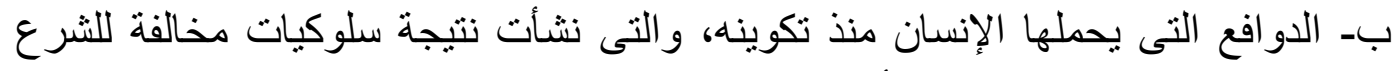

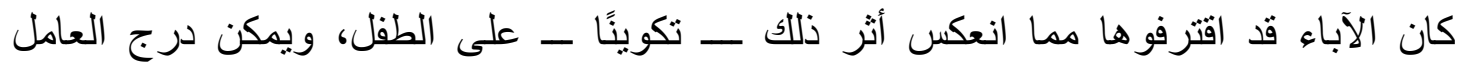




$$
\text { الور اثى ضمن هذه الدو افع. }
$$

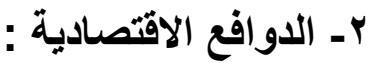

إن هذه الدو افع مما تشترك فيها ضروب العنف الأخرى مع العنف الأسرى، إلاّ أن الاختلاف بينهما كما سبق أن بينّا هو في الأهداف التى ترمى من ور اء العنف العنف بدافع اقتصادى.

ففى محيط الأسرة لا يرى الأب الحصول على منافع اقتصادية من وراء استخدامه العنف

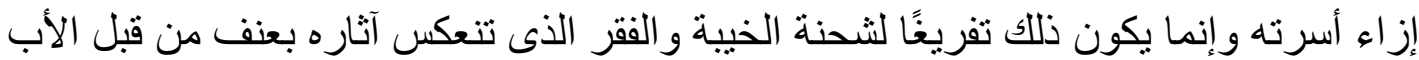

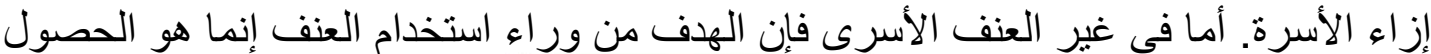

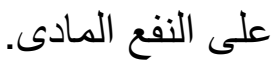

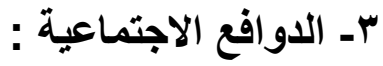

إن هذا النوع من الدو افع يتمثل فى العادات والتقاليد التى اعتادها مجتمع ما والتى تتطلب

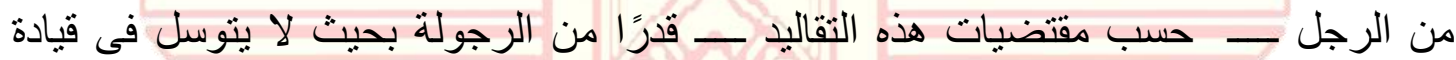

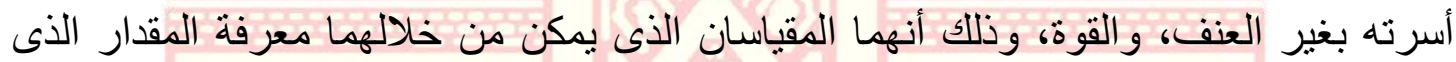

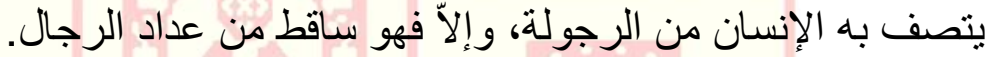

إن هذا النوع من الدو افع يتناسب طرديًا مع الثقافة التى يحملها المجتمع، وخصوصيًا الثقافة

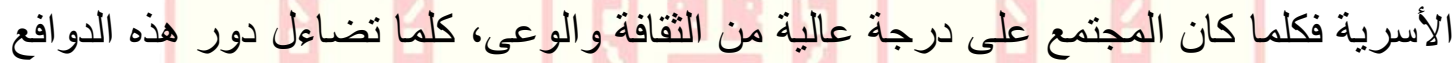

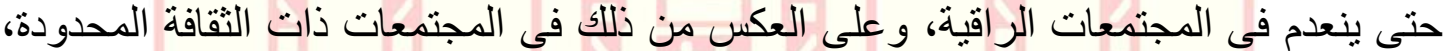

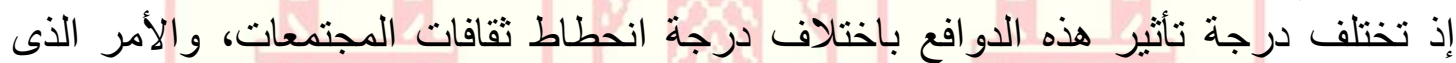

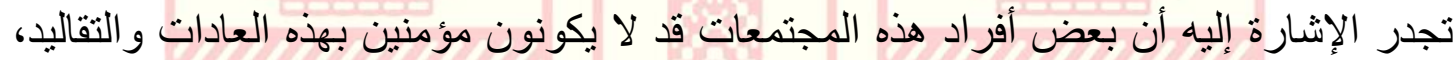

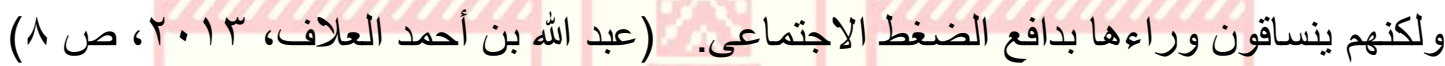

\section{حجم المشكلة عالميًا وإقليميًا:}

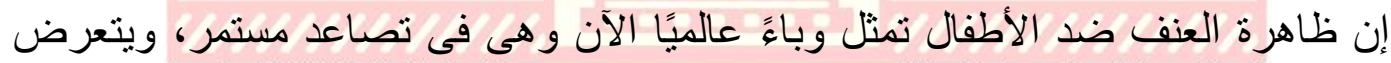

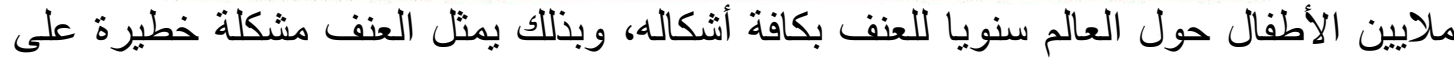

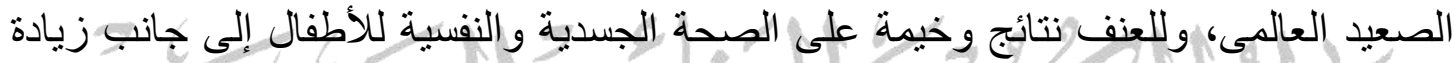

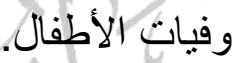

وعلى المستوى الإقليمى في منطقة الثرق الأوسط تنتشر أيضًا هذه الظقاهرة بشكل كبير بما يلى ذلك من تأثير شديد فى أجيال المستقبل، وقد طلبت العيت الجمعية العامة للأمم المتحدة من الأمين

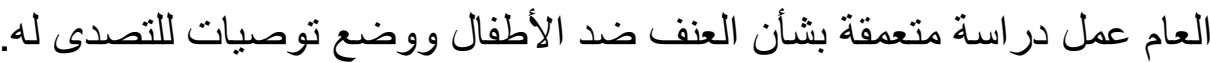

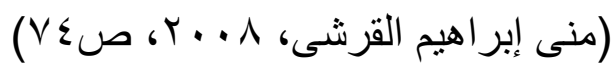

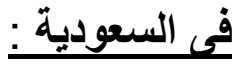

أظهرت نتائج دراسة حديثة أجر اها مركز أبحاث مكافحة الجريمة بوزارة الداخلية مؤخرًا،

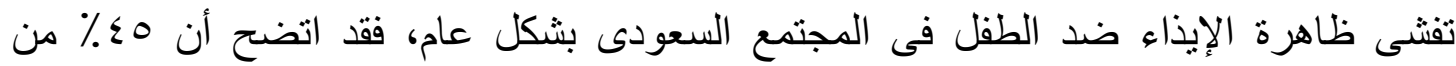




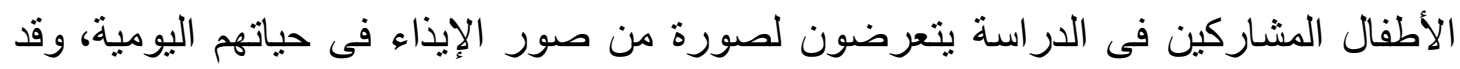

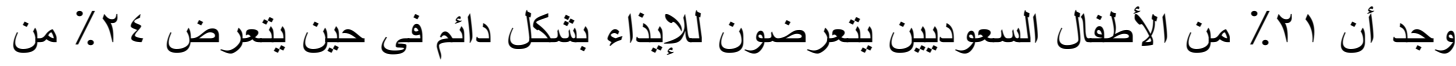
الأطفال السعوديين للإيذاء أحيانًا.

تابعت "الجمعية الوطنية لحقوق الإنسان" بفروعها المنتشرة فى جميع مناطق المملكة عدد

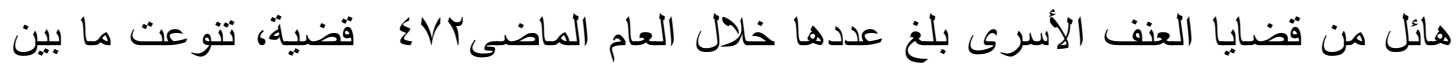
عنف نفسى وبدنى من قبل أفراد الأسرة، وكان ضحان ضحيتها إما الزوجة، أو الأطفال الطفال.

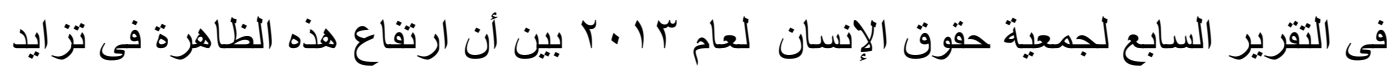

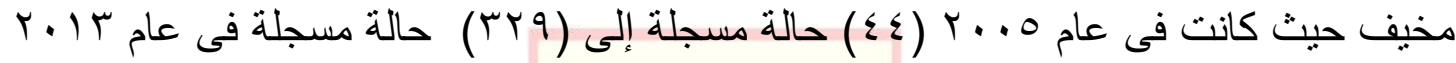

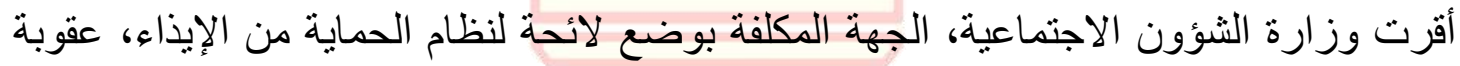

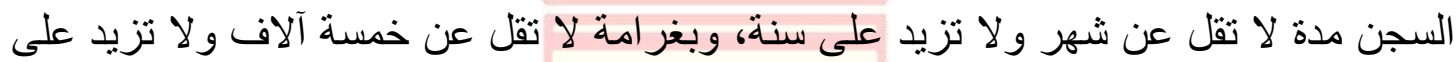

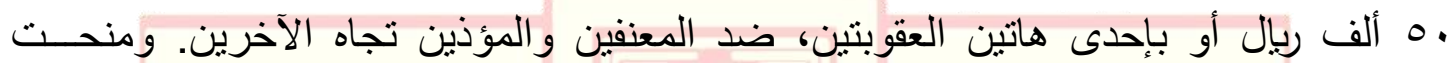

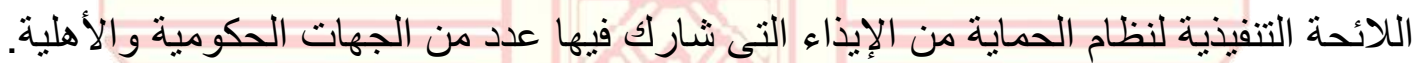

\section{http://www.assakina.com.}

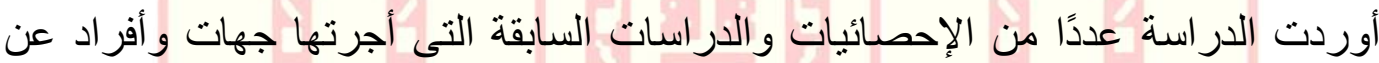

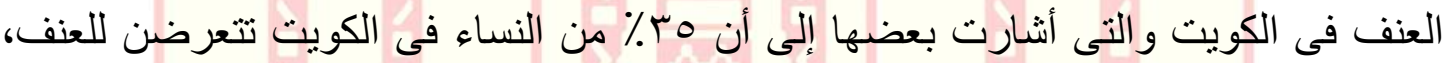

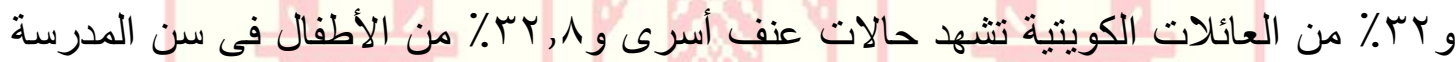

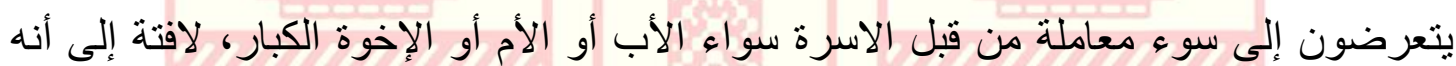

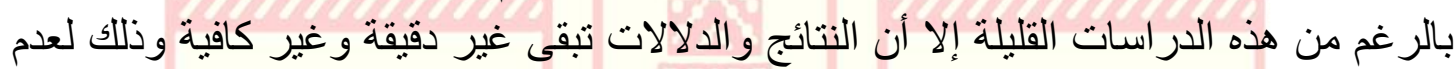
وصول جميع حالات العنف الأسرى إلى الجهات الرسمية.

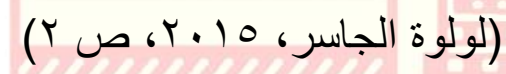

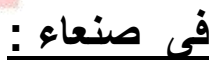

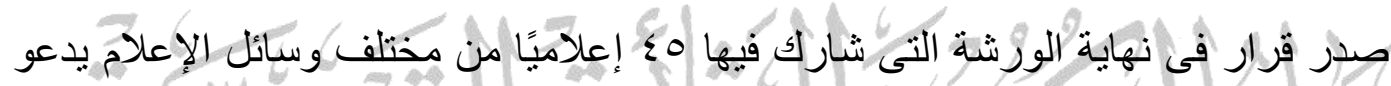
إلى إنر الك الأطفال فى إعداد وبث البرامج الإعلامية الموجهة لحمايتهم من العنف أو التعريف التهايف بحقو فه, و إلى إدماج حقوق الطفل وحمايته ضمن مناهج التعليم العام و العالى

$\underline{w w w . f e l i x n e w s . c o m / n e w s ~}$

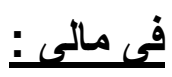

يتم بيع الأطفال كأى سلعة، ويتعرضون للاعتداء تجاريًا، وتثشير الإحصائيات الرسمية إلى في إنى

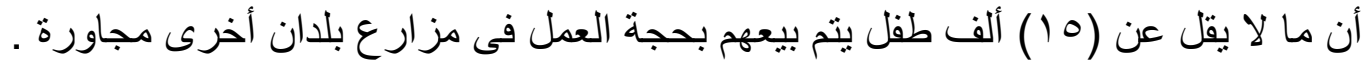


أكد مصدر طبى مختص لوكالة أنباء القس أن • ^٪ من الأطفال الذين يتعرضون للمعاملة السيئة سيتصرفون مستقبلاً بشكل سيئ مع أطفالهم أيضًا.

في ألمانيا :

قدرت الرابطة المهنية لأطباء الأطفال والنانشئة فى ألمانيا نسبة الأطفال الذين يتعرضون

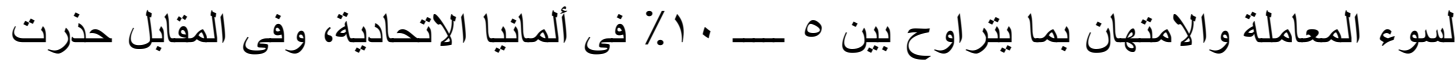

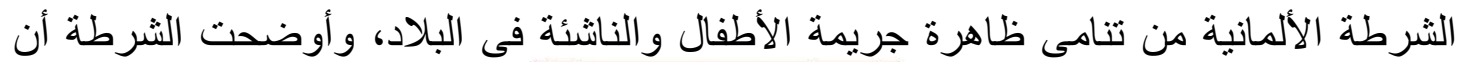

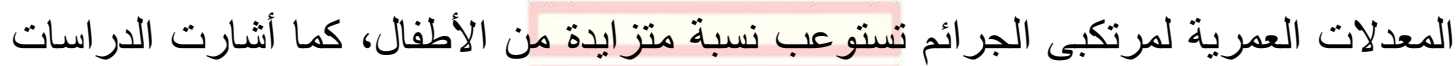

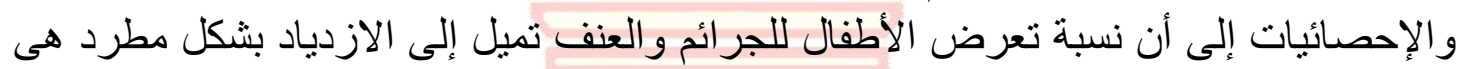

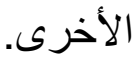

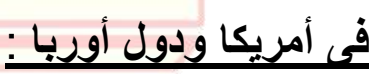

يوجد مليونا طفل يعانون من أثكال متعددة من العنف و الاضطهاد من قبل الكبار.

منظمة العمل الدولية :

ذكرت منظمة العمل الدولية إلى أن عدد الأطفال الذين يعملون بشكل غير مستقر يبلغ

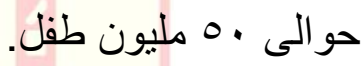

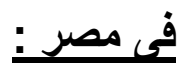

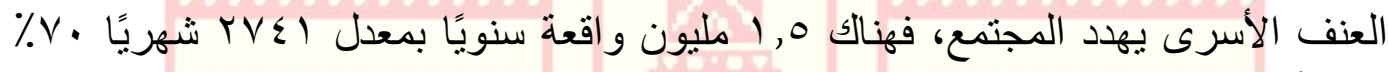

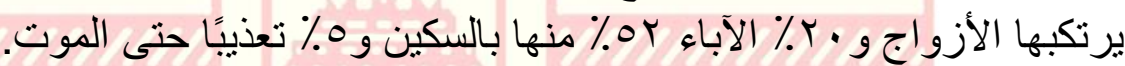

وهذه ظاهرة تسمى "العنف الأسرى"، حيث أكدت إحصائية للمركز القومى للبحوث

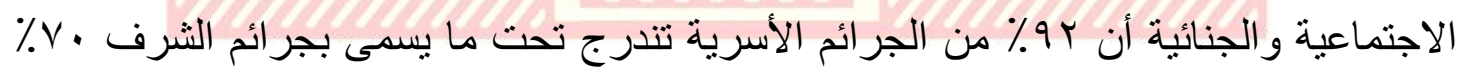

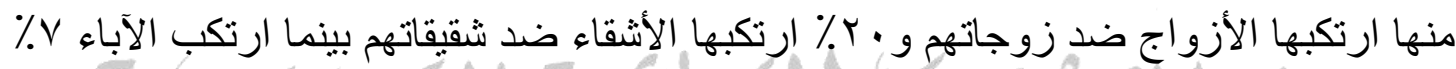

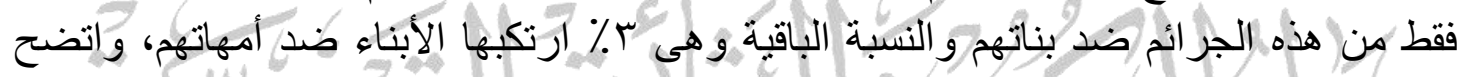

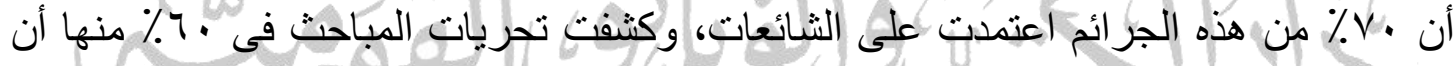

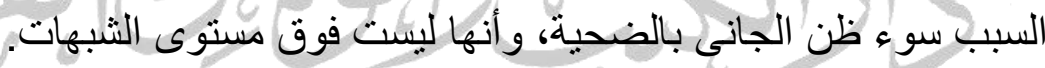

وعن أداة الجريمة قالت الإحصائية، إن به \% من هذه الجرائم ترتكب بواسطة السكين

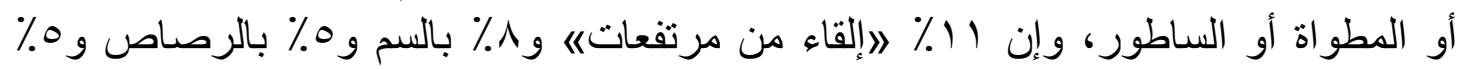

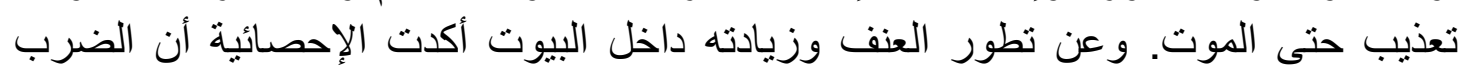

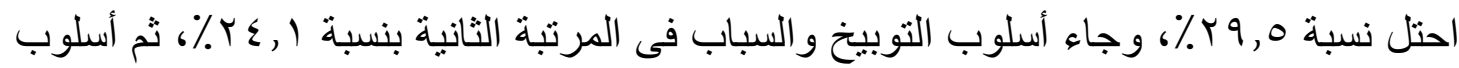

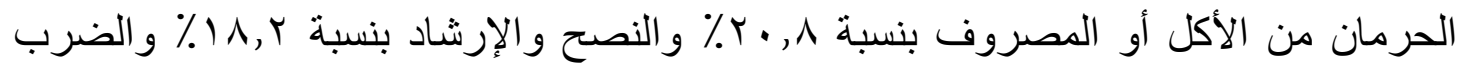

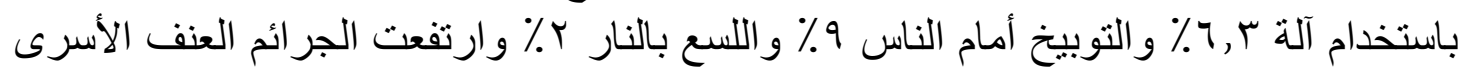

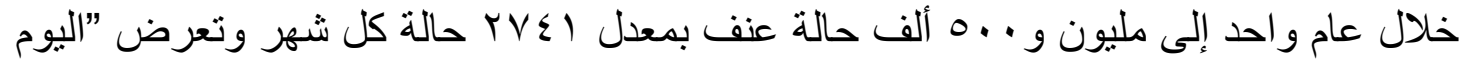

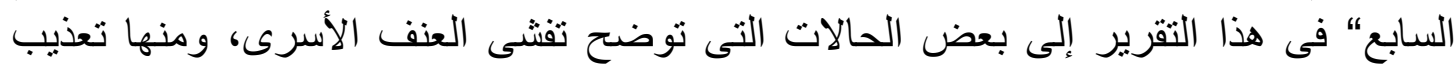




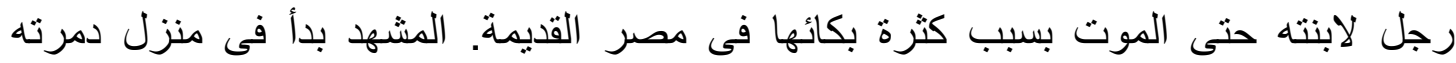

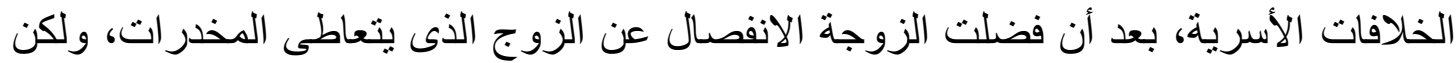

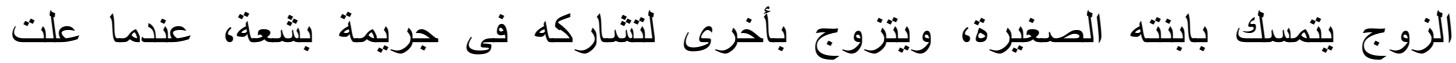

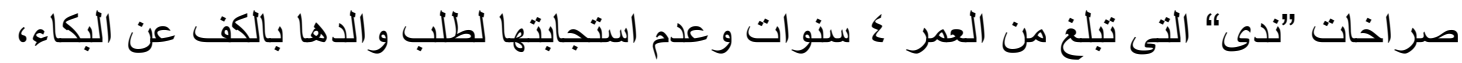

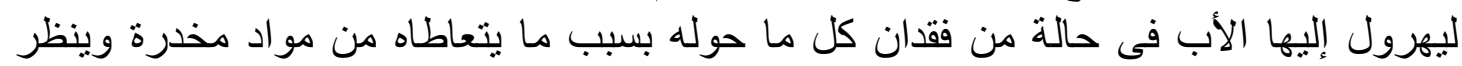

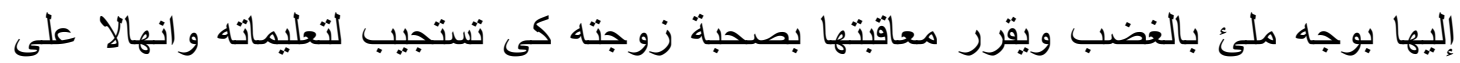

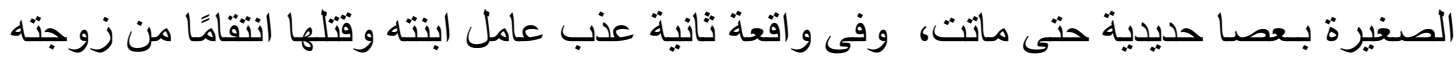

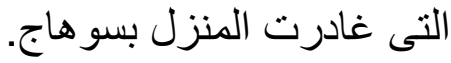

\section{www.aranthropos.com}

نتائج العنف :

إن الأضرار المترتبة على العنف لا تنال من مورس العنف عليهم فحسب، و وإنما تمتد

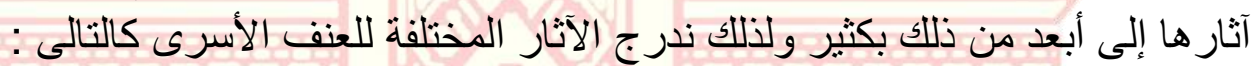
أــــــ أثر العنف فى ضحاياه : هناك آثار كثيرة على من مورس العنف الأسرى فى حقه منها : أـــــبب العنف فى نشوء العقد النفسية التى قد تتطور ونتفاقم إلى حالات مرضية.

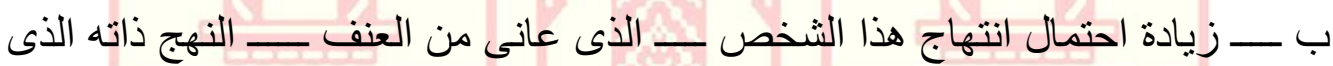
مورس فى حقه. r أثر العنف على الأسرة إن أثر العنف لو توقف فى حدود الفرد الذى عانى من العنف لكان الخطب أهون، ولكن

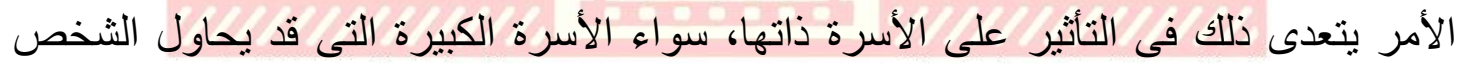
الذى بعنف انتقامه منها، أو التى سيكوِّنها مستقبلاً.

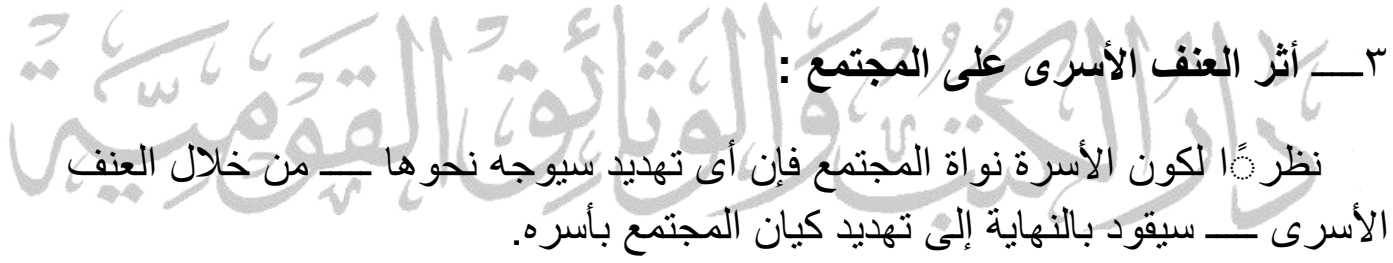

نشير إلى أن الإسلام دعا إلى نبذ العنف بكافة أنواعه، و على جميع الأصعدة، وخصوصًا

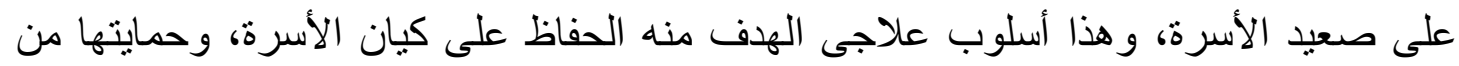

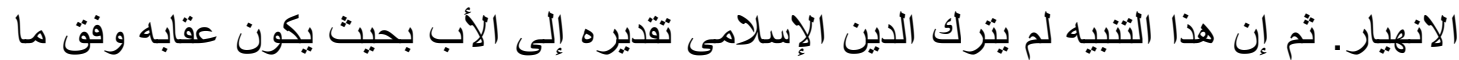

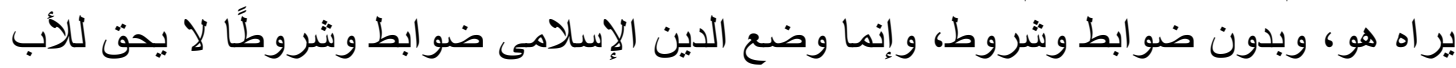
أن يتخطاها و إلاّ كان مخالفاً للأحكام الثرو وية. ا ــــإن الهدف من التنبيه التى أقرها الدين الإسلامى إنما هو إيقاف المخطئ على خطئه، كى 
لا يعود لمنله، وليس الهدف من التتبيه هو الاتتقام والتثفى من المعاقب.

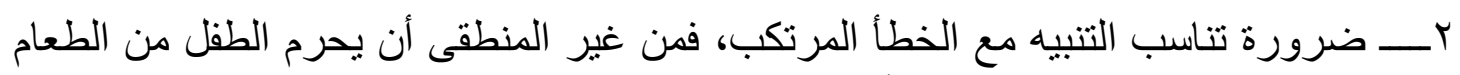
طبلة يوم كامل لمجرد مشيه حافيًا مثلاً.

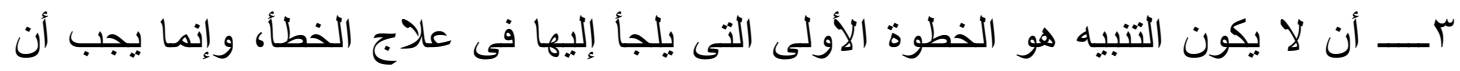
تسبقه مرحلة النصح ولفت النظر كلاميًا حسب، فإن تكرر ذللك يمكن عندها اللجوء إلى التنبيه.

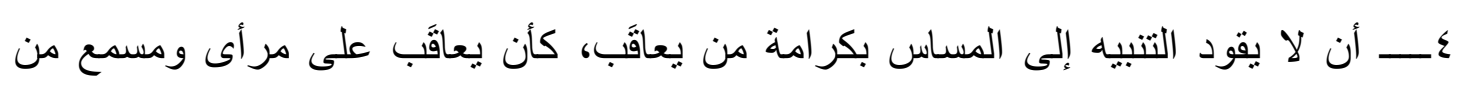
الآخرين، و إنما تر اعى السرية فى ذلإن قدر الإمكان.

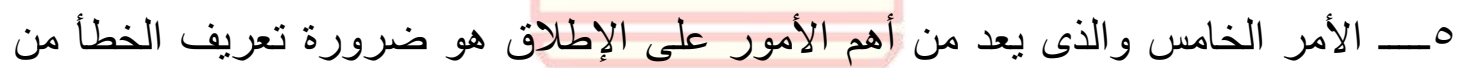

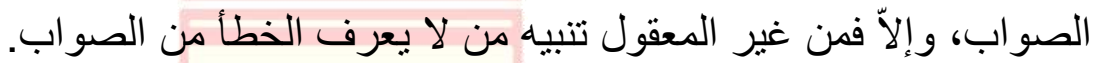

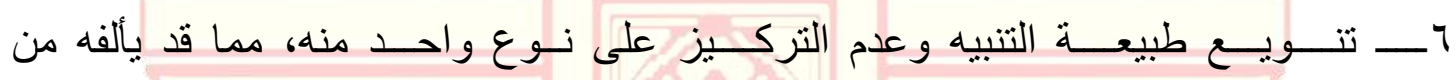

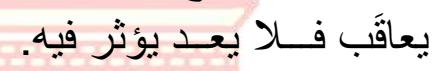

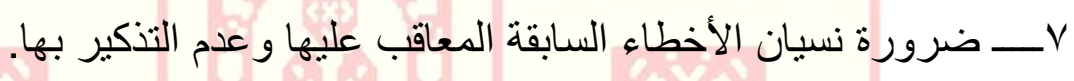

\section{(Al-alaf@hotmail.com )}

\section{الجهود المبذولة للحد من العنف ضد الأطفال :}

\section{المجلس القومى للطفولة والأمومة :}

فى إطار الجهود التى ييذلها المجلس القومى للطفولة والأمومة للتصدى لظاهرة العنف

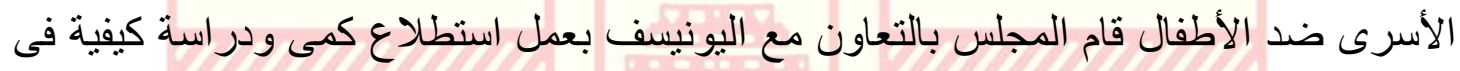

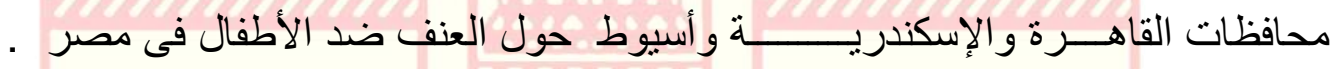

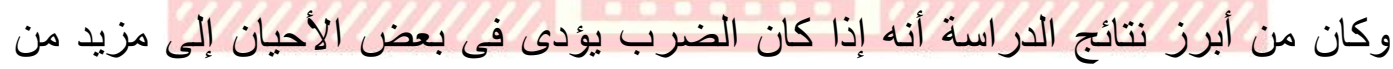

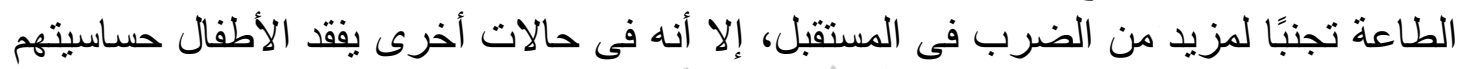

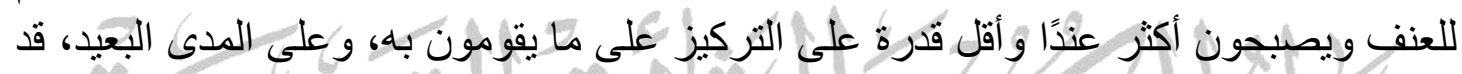
يؤدى العنف إلى أن يصبح الاطفال أنفسهم أكثر عنفًا إضنافة إلى معاناتهر من مشكلات نفسية.

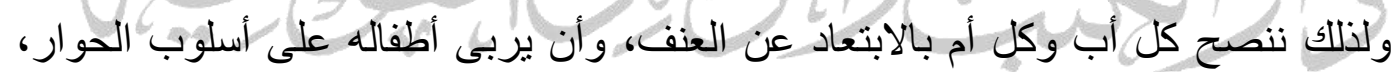

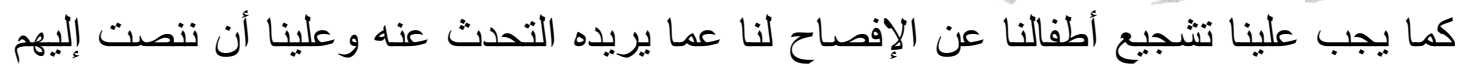

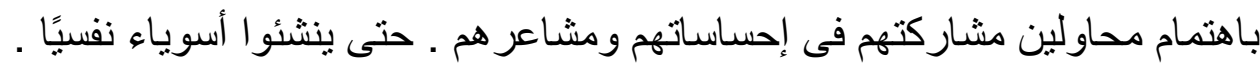
(akhbarel3alam.com)

\section{المجلس العربعى للطقولة و التنمية :}

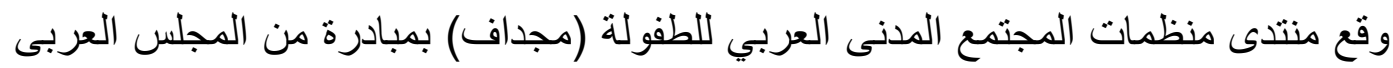

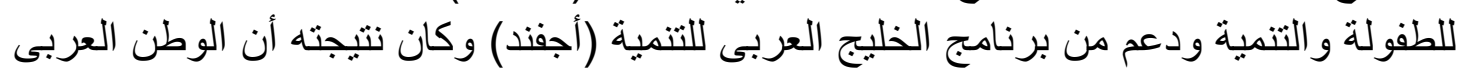


قد قطع شوطًا كبيرًا فى إدر الك مشكلة العنف الموجهة ضد الأطفال، وفى تطوير استر اتيجيات

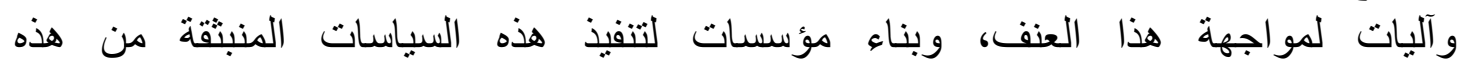
الاستر اتيجيات؛ هذا فضلاً عن سن التشريعات المختلفة الضرورية لتنفيذ هذه السياسات.

وعلى الرغم من التباين بين الدول العربية فى المنطلقات الفكرية، وفى طبيعة المؤسسات

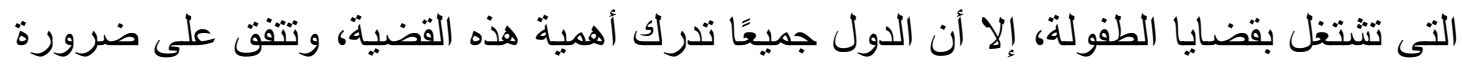

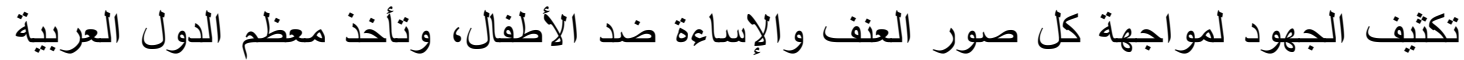

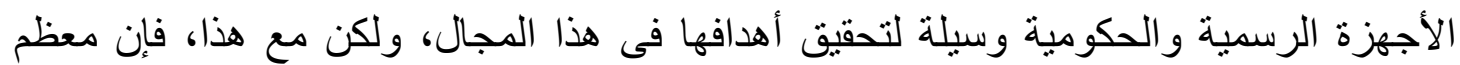

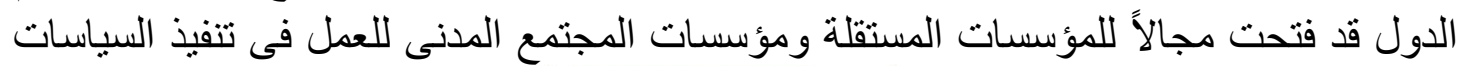
الخاصة بالطفولة وفقًا لاعتماد مبدأ الثر اكة فى تنفيذ السياسيات الاجتماعية، ولقد انتهى المؤتمر

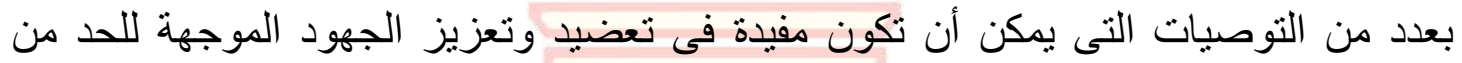

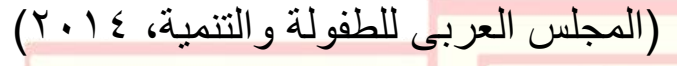

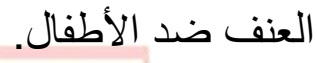
المؤثمرات :

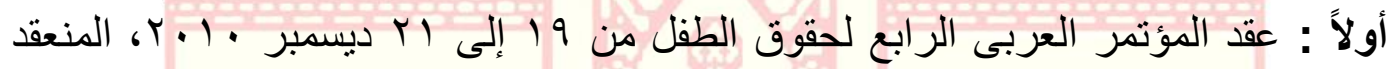
فى مدينة بمر اكث بالمملكة المغربية ولقد توصل إلى الى ما يلى :

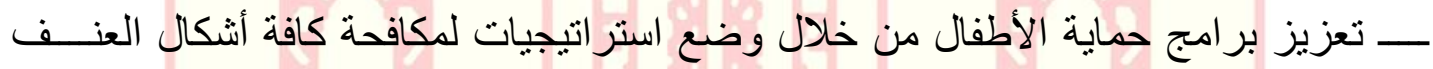

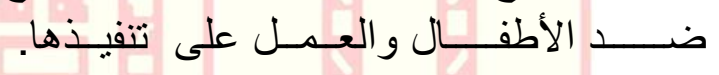

ــــالتوصيات العملية المنبثقة عن التقرير العربى المقارن لتنفيذ توصيات دراسة الأمين العام

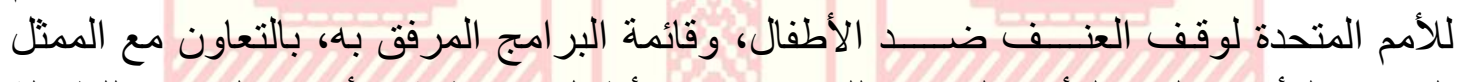

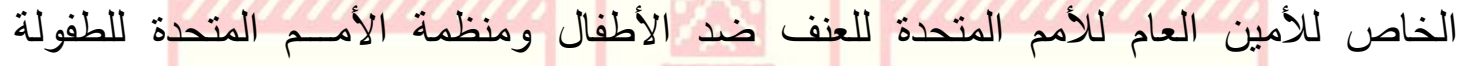

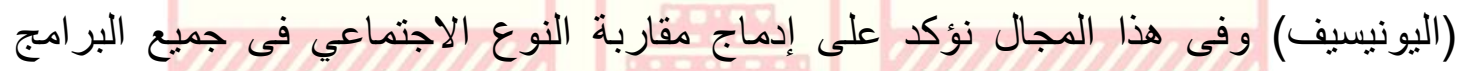

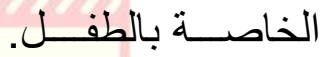

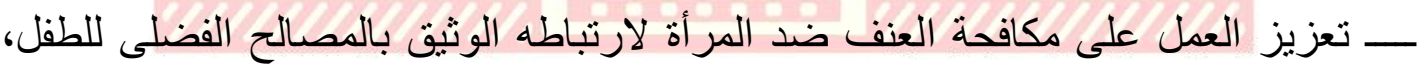

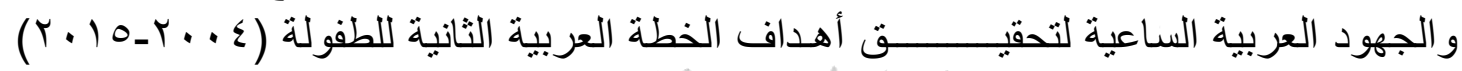

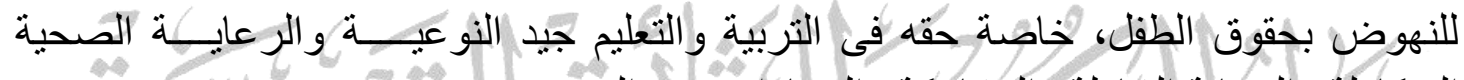
المتكماملة و الحماية الثشاملة والمشاركة و المساو اة و عدم التمبيز.

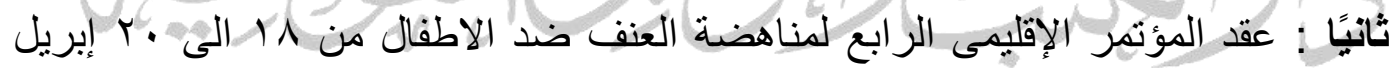

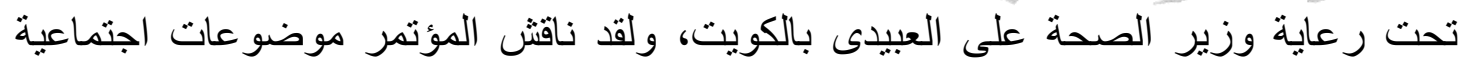

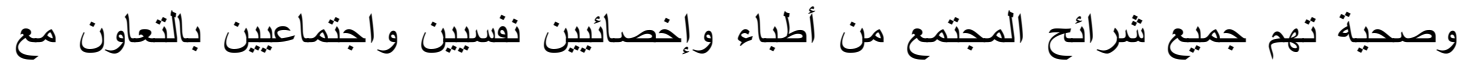
وزارتى الداخلية والتربية وغير هم وذللك لأهمية الموضوع عناعن واعتبار الطفل هو نواة المجتمع.

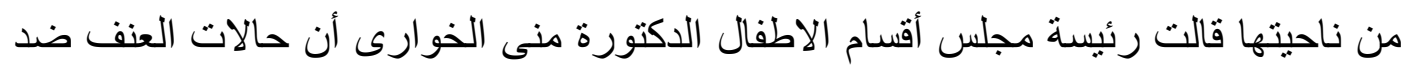

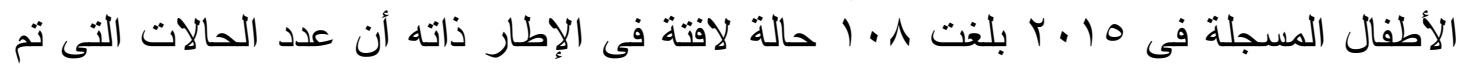

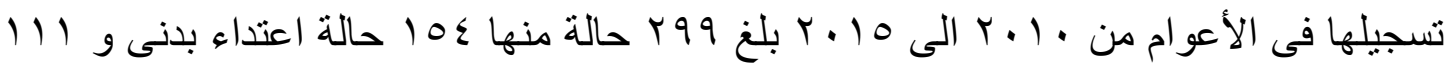

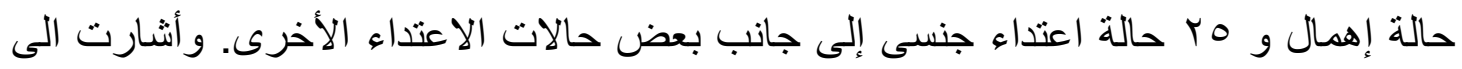


عدد الحالات خلال الأربع سنوات الماضية حسب الفئات العمرية إذ كانت هنالك 9V حالة من

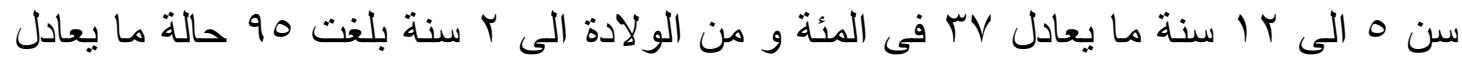

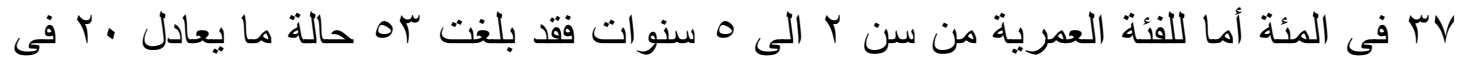

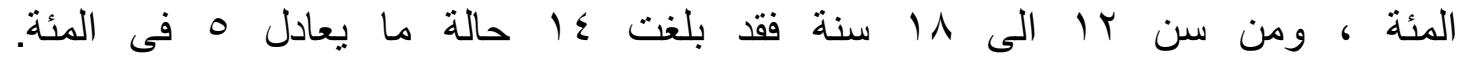

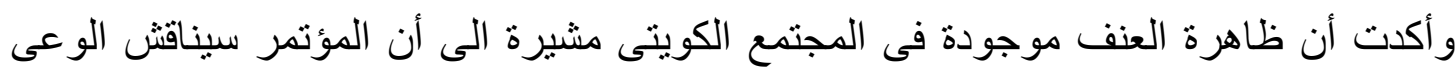

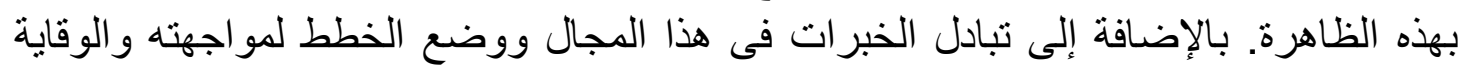

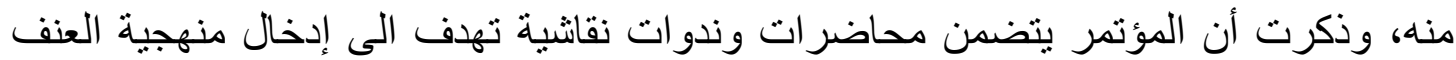

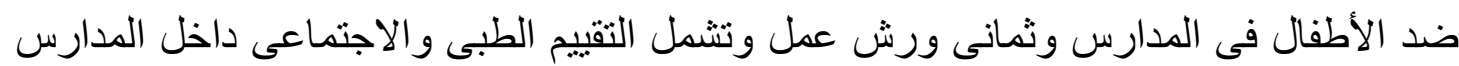
ودور الطب الشرعى فى الفحص على المعتدى عليهم.

وأثارت الى أن دور مكتب حقوق الطفل بتمثل بالإشراف على الفرق التابعة لله بالمستشفيات لضمان سرعة الاجراءات فى قضايا العنف ضد الأطفال وإيصالها إلى إدارة

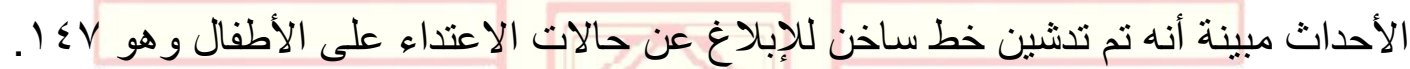

\section{: التوصيات}

اــــ زيادة الاهتمام بتدريس مو اد تخصص إدارة المنزل فى مر احل التعليم الأولى مع التركيز على اتخاذ القرار السليم لتحقيق الأهداف المنشودة وذلك بتوعية الجيل الجديد من الصغر وكيفية اتخاذ القرارات بأسلوب علمى .

r-ــ ضرورة إنشاء در اسات حرة فى تخصص إدارة مؤسسات الأسرة والطفولة فى كليات

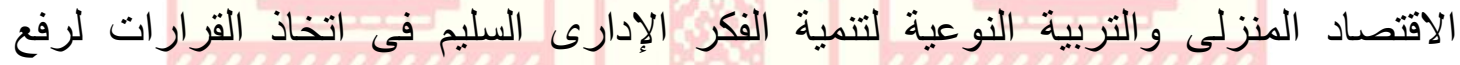

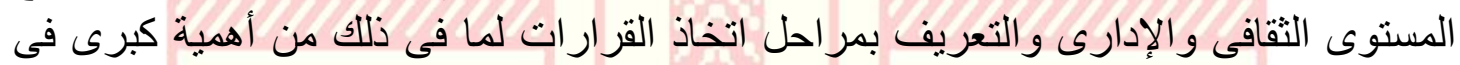

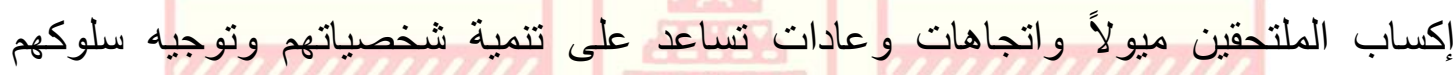
الوجهة الصحيحة الصنين

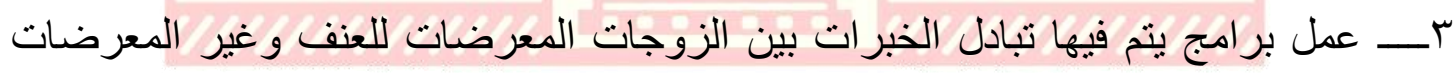
وذللك لتحسين كفاءة كل منهما .

عــ ضرورة توفيرح جهات رسمية أو شعبية تلجأ إليها الزوجات المتضررات من العنف الأسرى، تكون كفيلة بتقديم العون المادى والمعنوى، والرعاية الاجنماعية والنفسية لهؤلاء

○ــــرورة وضع خطة إعلامية تستهدف تسليط الأضواء على المشكلات التى تواجه المرأة

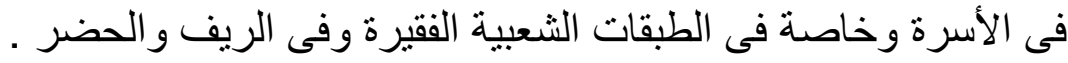

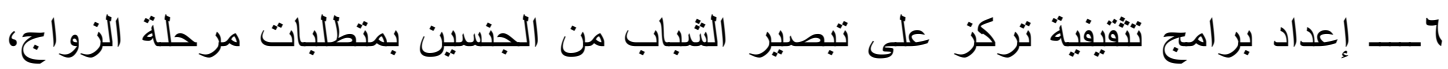
وتوضيح الحقوق و الواجبات المتبادلة، وترسيخ القيم و المعايير الدائمة للحياة الزوجية لئية حتى تلتعم

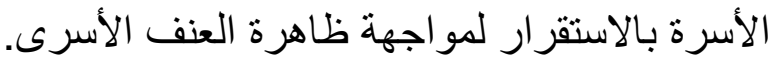

(أسماء عبده حسن محمود، T . . T، ص ب I ) 
ا_ أسماء عبده حسن محمود: ظاهرة العنف الأسرى وأثرها على اتخاذ الزوجة للقرارات

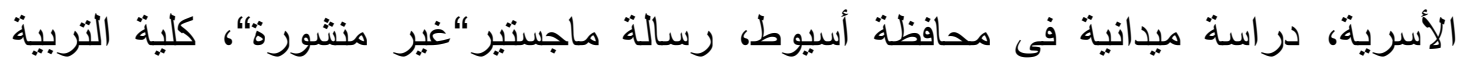

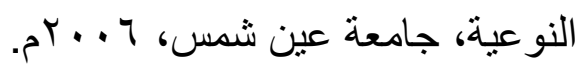

r بـ عبدالله بن أحمد العلاف: العنف الأسرى وآثاره على الأسرة و المجتمع، موقع صيد الفوائد على الثبكة العنكبوتية، www.saaid.net.

rـ- المجلس العربى للطفولة والتتمية. مجلة الطفولة والتتمية : دورية علمية متخصصة

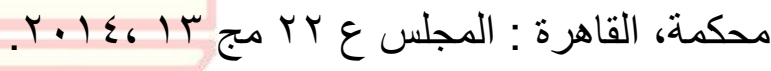

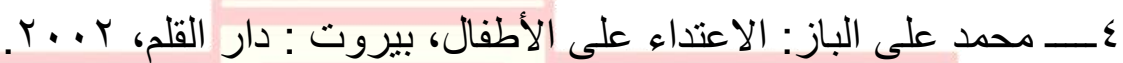

○ــ مدحت أبو النصر : العنف ضد الأطفال، المفهوم و الأشكال و العو امل، مجلة خطوة، المجلس

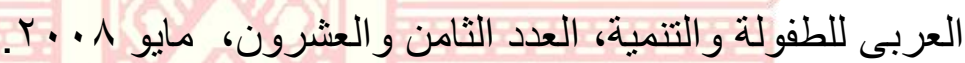

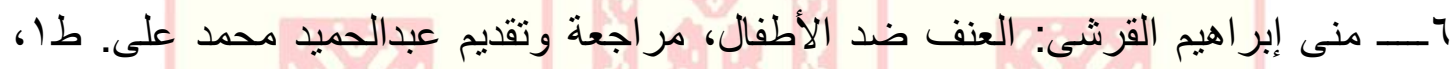

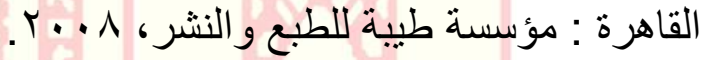

7- abdu09945.blogspot.com/2013/05/blog-post_7145.htm

akhbarel3alam.com

9 www.aranthropos.com.

10-mawdoo3.com 